\title{
The Effect of Bounding Attachment in Maternal Postpartum Blues Madura Ethnic
}

\author{
Adenia Dwi Ristanti*, Elly Dwi Masita \\ Faculty of Nursing and Midwifery, Nahdlatul Ulama University of Surabaya, Indonesia \\ *adeniadr@unusa.ac.id
}

\begin{abstract}
Postpartum blues is a transient state of increased emotional reactivity experienced by half of postpartum mothers within one week after delivery. The purpose of this study was to determine the effectiveness of bounding attachment in postpartum blues mothers. This type of research is a descriptive analytic study with a cross sectional design. Sampling using the rule of thumb sampling technique, all postpartum blues mothers for 3 months, from April to June 2020 and fulfilling the criteria of the researcher, can be used as respondents using the screening questionnaire Edinburgh Postnatal Depression Scale (EPDS) and the Postpartum Bonding Questionnaire (PBQ) questionnaire. The results showed that 15 respondents who experienced mild postpartum blues, the majority of 10 respondents, had good bounding attacment with their children. 18 respondents who experienced moderate postpartum blues had bad bounding attachment with their children and as many as 7 respondents who experienced severe postpartum also had bad bounding attachment to their children. There is a relationship between bounding attachment and postpartum blues with a $\mathrm{P}$ value of 0.29 , the better the bounding attachment of the mother, the lower the incidence of postpartum blues. So it can be assumed that the postpartum blues influences the bounding attachment. It is hoped that the results of this study will become a source of reference in the development of midwifery science to improve the quality of midwifery care, especially for maternal midwifery services with postpartum blues.
\end{abstract}

Keywords : Bounding Attachment, Postpartum Blues, Madura, Maternal 


\section{STRADA Jurnal Ilmiah Kesehatan}

DOI: $10.30994 /$ sjik.v9i2.426

ISSN: 2252-3847 (print); 2614-350X (online)

Vol.9 No.2 November 2020 Page.1072-1077

\section{BACKGROUND}

The period of pregnancy to delivery is a complex event that affects a mother. Many changes can cause disturbances from both physical and psychological aspects. These changes can become a depression after childbirth called postpartum blues. Postpartum blues is a transient state of increased emotional reactivity experienced by half of postpartum mothers within one week after delivery (Kroska and Stowe, 2020).

The postpartum blues is characterized by transient (fleeting) episodes of dysphoria, emotional overload, sadness, and mild memory disturbances that can affect $50 \%$ to $80 \%$ of hospitalized mothers on the first day after delivery. According to WHO during the postpartum period, $85 \%$ of mothers will experience some type of disorder or mood type (Fan et al., 2020). In most postpartum mothers the symptoms are mild and transient, but in some other postpartum mothers get prolonged sequelae. It is estimated that in Indonesia about $10-15 \%$ of women who experience postpartum blues, if they do not get good management, they tend to develop into non-psychotic postpartum depression (Kurniati, Sinrang and Syamsuddin, 2020).

Recent research has focused more on long-term causes and effects. The cause is thought to be multifactorial, such as socio-cultural, gynecological and obstetric factors, psychosocial factors (lack of social relationships and feelings of discontent in marriage and life pressure during pregnancy, poor family relationships), and hormonal factors. There is a relationship between demographic factors such as age, education level, marital status, socioeconomic status and the risk of mental disorders in postpartum. Another study stated that $26 \%$ of depressed patients were young (Lambermon et al., 2020).

Postpartum mothers who experience untreated depression during pregnancy have a sevenfold risk of developing postpartum blues than postpartum mothers who do not have symptoms of antenatal depression. Therefore, treatment of antenatal depression is important for the prevention of postpartum depression. In one small observational study involving 78 women who received a depression diagnosis in the first trimester of pregnancy, postpartum blues did not occur in all depressed women treated with either psychotherapy or pharmacotherapy, compared with $92 \%$ of women with untreated depression (Tobore, 2020).

Supportive and psychological interventions are more effective when performed after delivery than when they are initiated during pregnancy. Regular exercise, healthy nutrition, and adequate sleep are also recommended. Although the evidence to reduce the risk of postpartum blues on these baseline factors is still limited to the management of women with postpartum blues, it needs extensive management with both non-pharmacological and pharmacological terrapins. Through non-pharmacological therapy, namely psychological therapy, mothers can find the right way to deal with these depressive symptoms, overcome any disturbances that arise, or think positively when situations are depressed, one of which is by bounding attachment (Sarli et al., 2020).

Bounding attachment is a reflection activity of the mother's ability to accept her baby's presence and express her affection. This forms a strong bond between mother and baby. This inner bond can be built through interactions in the form of touch, caress, expressions of love, gaze full of love and affection from the mother for the baby. In this process, there is a merger based on genuine love and acceptance from parents for their children and providing nurturing support in their care (Adams et al., 2020).

The purpose of this study was to determine the effectiveness of bounding attachment in postpartum blues mothers. This study is important because there is still limited research in Indonesia that discusses bounding attachment in postpartum blues mothers. 


\section{STRADA Jurnal Ilmiah Kesehatan}

DOI: $10.30994 /$ sjik.v9i2.426

ISSN: 2252-3847 (print); 2614-350X (online)

Vol.9 No.2 November 2020 Page.1072-1077

\section{METODS}

This type of research is a descriptive analytic study with a cross sectional design. The population and sample of the study were all mothers with postpartum blues. The independent variables in this study were bounding attachment and the dependent variable for postpartum blues mothers. The instrument used a questionnaire sheet, then the data were analyzed using SPSS.

Sampling with the sampling technique used in this study is the rule of thumb, all postpartum women blues for 3 months, namely April to June 2020 and meet the criteria of the researcher can be used as respondents by using the Edinburgh Postnatal Depression Scale (EPDS) questionnaire and Postpartum Bonding Questionnaire (PBQ).

Inclusion criteria in this study were women with normal postpartum / SC, Primipara / multipara / grandemultipara, day 3 to day 7, able to communicate well, experiencing post partum blues, willing to be respondents. The exclusion criteria in this study were refusal to be a respondent, physical and mental illness, delivery with complications and high risk. Then the data was processed using SPSS 25.

\section{RESULTS}

Table 1. Frequency of Repondents Characteristics based on Demoghraphic Characteristic $(n=40)$.

\begin{tabular}{lcc}
\hline \multicolumn{1}{c}{ Characteristics } & Frequency & Percentage \\
\hline Age & 2 & 5 \\
<20 years old & 37 & 92,5 \\
21-35 years old & 1 & 2,5 \\
>35 years old & & \\
Education Level & 4 & 10 \\
Primary & 21 & 52,5 \\
Secondary & 15 & 37,5 \\
Higher & & \\
Occupation & 22 & 55 \\
Employed & 18 & 45 \\
Unemployed & & \\
Parity & 18 & 45 \\
Primipara & 10 & 25 \\
Multipara & 12 & 30 \\
Grandemultipara & & \\
Type of Labor & 13 & 32,5 \\
Caesarean Sectional & 27 & 67,5 \\
Normal & & 42,5 \\
Bounding Attachment & 17 & 57,5 \\
Good & 23 & \\
Bad &
\end{tabular}

Based on the frequency distribution table of the characteristics of the respondents, it is known that the majority of respondents are 21 to 35 , as many as 37 respondents $(92.5 \%)$. The number of characteristics based on education shows that secondary education is 21 respondents $(52.5 \%)$. In terms of parity characteristics, most of the 18 respondents $(45 \%)$ were primiparous. The type of delivery was 27 respondents $(67.5 \%)$ indicating normal delivery and 23 respondents (57.5\%) mostly were not good at doing bounding attachments. 
Hypothesis

To calculate the hypothesis test, the researcher processed the data using SPSS 25. The researcher used the chi-square statistical test.

Table 2. The Effect of Bounding Attachment in Maternal Postpartum Blues Madura Ethnic

\begin{tabular}{|c|c|c|c|c|c|c|c|c|}
\hline \multirow[t]{3}{*}{ No } & \multirow[t]{3}{*}{ Postpartum blues } & \multicolumn{4}{|c|}{ Bounding Attachment } & \multirow{2}{*}{\multicolumn{2}{|c|}{ Total }} & \multirow{3}{*}{$\begin{array}{l}\mathrm{P} \\
\text { Value }\end{array}$} \\
\hline & & \multicolumn{2}{|c|}{ Good } & \multicolumn{2}{|c|}{$\mathrm{Bad}$} & & & \\
\hline & & $\mathrm{f}$ & $\%$ & $f$ & $\%$ & $\mathrm{f}$ & $\%$ & \\
\hline 1 & mild & 10 & $66,7 \%$ & 5 & $33,3 \%$ & 15 & $100 \%$ & 0,29 \\
\hline 2 & Moderate & 7 & $38,9 \%$ & 11 & $61,1 \%$ & 18 & $100 \%$ & \\
\hline 3 & Severe & 0 & $0 \%$ & 7 & $100 \%$ & 7 & $100 \%$ & \\
\hline & Total & 17 & $42,5 \%$ & 23 & $57,5 \%$ & 40 & $100 \%$ & \\
\hline
\end{tabular}

Based on table 2, it is known that 15 respondents who experienced mild postpartum blues, the majority of 10 respondents, had good bounding attacment with their children. 18 respondents who experienced moderate postpartum blues had a bad bounding attachment with their children and as many as 7 respondents who experienced severe postpartum also had bad bounding attachment to their children. The results of statistical tests using the chi square showed the effect of postpartum blues on bounding attachment.

\section{DISCUSSION}

Evaluation of postpartum mothers with possible postpartum blues requires careful history taking to confirm the diagnosis, identifying whether other disorders are present, and managing medical and psychosocial problems that have contributed to it. About $70 \%$ of new mothers have mild depressive symptoms which generally peak in the 2 to 5 day range after delivery. These symptoms usually begin to subside spontaneously within 2 weeks, but if not detected quickly and treated late, it can develop into a depression called the postpartum blues(Alves et al., 2019).

A meta-analysis study showed that postpartum mothers who were treated with psychosocial interventions were less likely to remain depressed at 1 year postpartum than women who received only standard care in primary care. For mothers with moderate symptoms of illness, and for those with mild symptoms who cannot respond to psychosocial interventions alone, formal psychotherapy such as cognitive behavioral therapy and interpersonal therapy may be recommended. This therapy is given in groups or individually over a period of 12 to 16 weeks. Cognitive-behavioral therapy focuses on changing maladaptive thought patterns, behaviors, or both, to produce positive changes in emotional states. Meanwhile, interpersonal therapy is mood therapy for interpersonal relationships and focuses on improving relationships to help with the transition of a woman's role into a new parent (Rezaie-Keikhaie et al., 2020).

For postpartum mothers with mild symptoms, psychosocial interventions that can be given for example are increasing support, such as peer support, bounding attacment, and counseling conducted by professional health practitioners. These interventions are the first line in postpartum blues care (Kallem et al., 2019). Bounding is a step to express feelings of areksi (affection) by the mother to her baby immediately after birth, while attachment is the interaction between mother and baby specifically all the time. The bonding process between mother and baby begins with affection for the baby, and can start from pregnancy. The inner bond between babies and parents is closely related to healthy psychological growth and development of babies. Family is the first and foremost environment for 


\section{STRADA Jurnal Ilmiah Kesehatan}

DOI: $10.30994 /$ sjik.v9i2.426

ISSN: 2252-3847 (print); 2614-350X (online)

Vol.9 No.2 November 2020 Page.1072-1077

babies. It is from this environment that babies learn to form patterns of relationships with other people. Parental inhibitory behavior can affect the bond of affection to become sibling rivalry(Simpson et al., 2018). So it requires the support of families who understand and know the benefits of bounting attacment so that sibling rivalry does not occur. The development of research results on the success of bounding attachments shows the development of predisposing factors as a form of interrelated scientific development. How the concept of bounding attachment is constructed and interacted with other studies such as the success of early initiation of breastfeeding, postpartum maternal spicology and husband or family support at this time are seen indirectly only as a connecting factor.

A postpartum mother who is depressed should not hesitate to always tell her complaints to family or other people who can understand and can help. In addition, adequate rest is also needed in order to avoid feelings of depression due to fatigue, for example by asking for help from other people who can be trusted to take care of the baby. In terms of diet, it must be given regularly with a healthy and balanced menu followed by moderate exercise so that the mood can improve.

\section{CONCLUSION}

There is a relationship between bounding attachment and postpartum blues with a $\mathrm{P}$ value of 0.29 , the better the bounding attachment of the mother, the lower the incidence of postpartum blues. So it can be assumed that the postpartum blues influences the bounding attachment. It is hoped that the results of this study will become a source of reference in the development of midwifery science to improve the quality of midwifery care, especially for maternal midwifery services with postpartum blues.

\section{REFERENCES}

Adams, G. C. et al. (2020) 'Attachment impacts cortisol awakening response in chronically depressed individuals', Psychoneuroendocrinology, 120, p. 104778. doi: https://doi.org/10.1016/j.psyneuen.2020.104778.

Alves, S. et al. (2019) 'Predictive validity of the Postpartum Depression Predictors Inventory-Revised (PDPI-R): A longitudinal study with Portuguese women', Midwifery, 69, pp. 113-120. doi: https://doi.org/10.1016/j.midw.2018.11.006.

Fan, Q. et al. (2020) 'Prevalence and risk factors for postpartum depression in Sri Lanka: A population-based study', Asian Journal of Psychiatry, 47, p. 101855. doi: https://doi.org/10.1016/j.ajp.2019.101855.

Kallem, S. et al. (2019) 'Mothers' Mental Health Care Use After Screening for Postpartum Depression at Well-Child Visits', Academic Pediatrics. Elsevier, 19(6), pp. 652-658. doi: 10.1016/J.ACAP.2018.11.013.

Kroska, E. B. and Stowe, Z. N. (2020) 'Postpartum Depression: Identification and Treatment in the Clinic Setting', Obstetrics and Gynecology Clinics of North America, 47(3), pp. 409-419. doi: https://doi.org/10.1016/j.ogc.2020.05.001.

Kurniati, Y., Sinrang, W. and Syamsuddin, S. (2020) 'Postpartum blues syndrome: Serum zinc and psychosocial factors', Enfermería Clínica, 30, pp. 18-21. doi: https://doi.org/10.1016/j.enfcli.2019.07.019.

Lambermon, F. et al. (2020) 'Maternal self-care in the early postpartum period: An integrative review', Midwifery, 90, p. 102799. doi: https://doi.org/10.1016/j.midw.2020.102799.

Rezaie-Keikhaie, K. et al. (2020) 'Systematic Review and Meta-Analysis of the Prevalence of the Maternity Blues in the Postpartum Period', Journal of Obstetric, 


\section{STRADA Jurnal Ilmiah Kesehatan}

DOI: $10.30994 /$ sjik.v9i2.426

ISSN: 2252-3847 (print); 2614-350X (online)

Vol.9 No.2 November 2020 Page.1072-1077

Gynecologic \& Neonatal Nursing, 49(2), pp. 127-136. doi: https://doi.org/10.1016/j.jogn.2020.01.001.

Sarli, D. et al. (2020) 'Early screening of baby blues based on Android applications: Firstweek postpartum', Enfermería Clínica, 30, pp. 129-132. doi: https://doi.org/10.1016/j.enfcli.2019.11.038.

Simpson, J. A. et al. (2018) 'Changes in attachment orientations across the transition to parenthood', Journal of Experimental Social Psychology, 39(4), pp. 317-331. doi: https://doi.org/10.1016/S0022-1031(03)00030-1.

Tobore, T. O. (2020) 'On maternal Post-Partum/Natal depression. A global underrecognized problem and the need for better Treatment strategies', Psychiatry Research, 290, p. 113163. doi: https://doi.org/10.1016/j.psychres.2020.113163. 